European journal of American studies

$10-2$ | 2015

Summer 2015, including Special Issue: (Re)visioning

America in the Graphic Novel

\title{
Making Progress: Ellison, Rinehart, and the Critic
}

\section{Cheryl Alison}

\section{(2) OpenEdition}

\section{Journals}

Electronic version

URL: https://journals.openedition.org/ejas/11062

DOI: 10.4000/ejas. 11062

ISSN: 1991-9336

Publisher

European Association for American Studies

\section{Electronic reference}

Cheryl Alison, "Making Progress: Ellison, Rinehart, and the Critic", European journal of American studies [Online], 10-2 | 2015, document 13, Online since 14 August 2015, connection on 08 July 2021. URL:

http://journals.openedition.org/ejas/11062 ; DOl: https://doi.org/10.4000/ejas.11062

This text was automatically generated on 8 July 2021 .

Creative Commons License 


\title{
Making Progress: Ellison, Rinehart, and the Critic
}

\author{
Cheryl Alison
}

For nearly forty-three years following the successful publication of Invisible Man in 1952, Ralph Ellison worked on a second novel without settling it into a final, publishable form. After Ellison's death on April 16, 1994, John Callahan, Ellison's literary executor, went to work on the pages and computer files accumulated during the second novel's drafting. As a result, Juneteenth was published in 1999: an approximately 350-page book, culled from thousands of Ellison's typed, written, and digitally stored pages. Not long after, Adam Bradley joined Callahan in another sustained period of manuscript and archive study, and the pair spent over a decade parsing Ellison's extensive array of written material and files, now housed in the Library of Congress. In 2010, Three Days Before the Shooting... emerged from this collaboration. This latter publication broadened the scope of Juneteenth's focus and, in its own size and lack of cohesion, perhaps more nearly mirrored Ellison's fragmentary working draft. The 2010 book contains close to 1100 pages of Ellison's notes and drafts.

More than with evaluating the success of these publications, the present essay is concerned on a broad scale with the stakes of our engaging posthumously the author's accumulation of manuscript materials and with the kinds of conclusions that we can draw from this engagement. Perhaps unsurprisingly, when Callahan and Bradley address Ellison's long-term process and growth of material, specific language emerges. Arguably, this language articulates a perspective both authors to some degree assume, one I will highlight and call into question as a specific instance of-and a synecdoche for-wider interpretive tendencies that reduce Ellison's substantial complexity. In his Introduction to Juneteenth, Callahan describes Ellison's work as "Always in progress" (Callahan, Juneteenth xxxi), a description and logic that Bradley echoes and takes further in the title of his 2010 book, Ralph Ellison in Progress: From Invisible Man to Three Days Before the Shooting.... The phrase "in progress" encourages us to read Ellison's work on the draft, his more or less four decades of work, as getting somewhere or at least heading there. The book's subtitle further bears out such a reading; it indicates a 
movement from here to there, and thereby also implies development toward an endpoint Ellison did not live to reach but toward which he was presumably heading.

such reasoning informs Ralph Ellison in Progress, including its author's approach to the Ellison drafts. The study intriguingly works backwards, reading Invisible Man through the lens of the unfinished second novel-rather than, as has been common, seeing the second work as a failed follow-up to Invisible Man's success (14). But the impulse to narrativize Ellison's body of work relies upon the trajectory inherent in narrative structure. Ralph Ellison in Progress sees "both novels [as] bound together in Ellison's singular pursuit of a literary idea," the novel that might be adequate to America and Americans (18). The trajectory Bradley seeks to make visible, namely "the long trajectory of Ellison's novelistic career," characterizes his close, archival readings of Ellison's manuscripts and makes for an interpretative model not always supported by the specifics of the material. Progress in this case becomes something made through the critical act.

Ralph Ellison in Progress is the prime critical text I engage in my discussion of Ellison and Ellison's compositional documents. This selection is due to how Bradley combines unusually careful attention to the author, and prolonged work with the Ellison archive, with the narrativizing impulse that I argue does not always best serve Ellison scholarship. His work, in other words, is among the most impressive available on the author; but it also represents what I contend is a limited style of approaching Ellison that pays insufficient attention to the real and valuable impediments Ellison continues to offer to straightforward models charting his creative and intellectual output. To further frame this comparatively brief treatment of a gargantuan amount of material, I use as a focusing lens one character in the Ellison canon, most readily identified as Rinehart, whose complexity makes him particularly Ellisonian. Through paying close attention to this character, in combination with Bradley's readings of the same, I hope to demonstrate that Ellison's compositional history has less linear development than Ralph Ellison in Progress despite its nuance seems to indicate, and I will make the case that my localized "character interpretation" has wider implications for how we encounter the author's work. Because my analysis here is concerned as much with how we read Ellison as it is with his primary material, I often come at the character from a tertiary perspective: reading Bradley reading Ellison. Although the Ellison character at issue is in many ways a continuously identifiable character, he also, as we will see, challenges the desire to plot his development.

When Ellison began thinking about his next project, following work on Invisible Man, he brought into the novel-to-be a character from his first novel. Readers of Invisible Man will be familiar with Rinehart, arguably Ellison's "most compelling" (Beavers 198) ) $^{\mathrm{ii}}$ character, and if the criticism is indicative, also his most contentious. ${ }^{\text {iii }}$ Simply put for now, as Ellison drafted the novel that would remain unfinished when he died, he went from calling the figure by the name immortalized in Invisible Man to casting him, finally, as Bliss, the child, and Adam Sunraider, the man. ${ }^{\text {iv }}$ Almost a figment as Rinehart in Invisible Man, he was to have had a starring role in the unfinished work. I more thoroughly detail the history of this second work and the character's place within it below; but, suffice it to say here, as he reworked the draft over the course of decades, Ellison again relegated the figure to the wings, where, as Sunraider, the once-prominent narrative actor instead became a mystifying prop. 
As may already be clear, my intent is not to solve the critically popular problem of the second novel's incompletion ${ }^{v}$ or of Rinehart-as-Sunraider's eventual (near-) dismissal from it. Rather, I will look at Bradley's treatment primarily of the second problem in order to draw out what I see as the complications inherent in the style of encountering Ellison he exemplifies. Bradley reads the character's presence in Ellison's drafting process so that "Rinehart" is but the first stage (itself involving varied spellings of the name, each of which Bradley places on a trajectory) of a development that will take us to "Bliss" and "Sunraider." As this sequence gets worked out in Bradley, or gets worked out as a sequence, each of these character facets is effectively made accessible to the logic of the diagram: simultaneously dividable and definable. In looking closely at the text published as Three Days Before the Shooting... by means of Callahan and Bradley's heroic joint efforts, I will suggest some of the ways in which the character remains more mutable across time and more self-continuous in this mutability than a progress-oriented interpretation allows.

One finds in contemporary critical work on Ellison a call for nuance: a call made in response to prior decades of readings establishing the author as by turns either politically conservative or radical; individualistic or race-oriented; culturally populist or elitist; aesthetically revanchist or avant-garde; critical of the US or devotedly nationalistic. The list goes on. ${ }^{\text {vi }}$ What I hope to demonstrate, in line with this desire for greater subtlety, is that paying attention to Ellison's most infamous character as he lives within and between the novels, as well as to the author's own varying disposition toward him, can reveal something far richer than a consistent progress. Further, it can take us into a line of interpretation and discussion arguably more in keeping with an author whose work manifests such impressive breadth and adaptability of thought and commitments-the same range that has often divided his critics.

Before continuing with Bradley's interpretation of Rinehart's place (and Sunraider and Bliss's) in the Ellison canon, background on the character's appearances in Ellison will be useful, beginning with Invisible Man and then turning to the second, unfinished novel. Since readers are likely familiar with the former work, I expand more upon the circumstances of the incomplete manuscript. I also include select critical treatments of the character's role in both works and in Ellison's compositional history where useful.

Readers of Invisible Man will know that Rinehart never materializes in the novel. Instead, he appears near its close as a set of signifiers, which when the invisible man dons the green glasses and wide hat, will lead him to be mistaken as Rinehart-a sharpie, numbers-runner, pimp, lover, briber, and reverend. Rinehart-as-disguise becomes the means through which the invisible man negotiates, by being misrecognized, the dangerous circumstances toward the novel's end: particularly the personal enmity of the Black Nationalist agitator, Ras the Destroyer, and his adherents. As a trickster style, a way of being or play(act)ing, Rinehart's precedent opens the invisible man up to a world of pliable identities and other possibilities previously unconsidered.

Invisible Man's drafts add a little more to the story. Both Bradley and Barbara Foley, the latter in Wresting with the Left (2010), have diligently exhumed the Rinehart Ellison cut out of Invisible Man in the drafting process: a vestige with similarities to Rinehart's later incarnation as Bliss-Sunraider in the unfinished second novel. In a cut scene from Invisible Man, the narrator learns details about Rinehart from a Harlem 
Brotherhood member named Julius Franklin, who remembers a more embodied and potentially more alarming figure than we get in the 1952 novel. In the eliminated section, for example, Franklin calls Rinehart a "dog" and says more directly what we are left to suspect in Invisible Man: that he is mixed up in every possible people-using racket. Recalling Rinehart's childhood in the South, Franklin also describes him as "one of these here little boy preachers" and wonders if he might be the same as "another [boy preacher] who had grown up and passed for white and become a wealthy broker, a country gentleman, and a reactionary writer on politics" (qtd. in Foley 306). vii

Notably, Bradley includes less and Foley rather more of the omitted material's portrait of Rine. Because Bradley uses Rinehart to demonstrate the connection-asprogress between Ellison's first and second novels, his argument relies upon a clear continuity between the Invisible Man draft Rinehart (a child preacher who might have grown up to become a racially passing, wealthy, and reactionary figure) and the child Bliss who becomes Adam Sunraider in the second novel. Without this draft identification, the only hints withinInvisible Man that the first novel's Rinehart is the second novel's Bliss-Sunraider are Rinehart's undeniable charisma (Senator Sunraider has "magnetism" (Ellison, Three Days 24)), his occasional role as a reverend, and the fact that one woman who mistakes the invisible man for Rinehart calls him "Bliss, daddyRinehart!" (Ellison, Invisible 494).

By contrast, Foley's interpretive goal relies upon showing Ellison's later elision of the Rinehart character's earlier connections to fascism. Of interest to Foley is how Rinehart's representation in the preliminary draft, and the potentially more vicious extent of his manipulation of social chaos dealt with there, reveals Ellison's continuing alliance with Marxist concerns at the time of its drafting: in this case, "the Marxist view of fascism as a chaotic manifestation of monopoly capitalism in crisis" (Foley 307). Long after Ellison overtly started backing away from the Communist Party, in other words, he still shared its ideological concerns. In her analysis of Ellison's character, Foley suggests a historical antecedent for Rinehart: Lawrence Dennis was also a child evangelist, an African American man passing for white, and particularly in the 1930s and 40s, a well-known advocate of and published author on American fascism. Unsupported by Ellison's own comments on the character, Foley nonetheless establishes strong correspondences between Dennis and Rinehart, positioning Ellison in relationship to historical Marxism, and establishing fascism's claim on Rinehart.

Rinehart functions in no small degree as a cypher: both a zero and a puzzle. As his later incarnation, Sunraider, will think to himself in the second novel: "Very well... but you'll have to admit that if I'm not all that you say I'm at least a walking personification of the negative" (Ellison, Three Days 408). Bradley's and Foley's divergent interpretative aims suggest that if interpretation always shapes its object, Rinehart risks being the interpretable object par excellence. The extensive Ellison archive only expands this interpretability, with (at least) a two-fold effect: on the one hand, an awesome sense of possibility for those of us quite "taken" by Rinehart, and on the other, the risk that, in essence, anything can be said. Rinehart can be both celebrated as undermining dogmatic forms of subjectivity (Bell 31-32) and condemned as a "boogey man of white sociology... a congealed set of social anxieties" (Heise 154) with at least some degree of support. Like Sunraider, he may not be "all that you say," but as "a walking personification of the negative" so much seems to fit, not because he really is a catchall, but because Ellison himself seems never to have finished conceptualizing Rinehart. In one of his 
notes on the character for the second work, he jotted the following: "But what is he?" (Ellison, "Opus II"; original underlining). The question, even 30 or 40 years later in the drafts that followed, seems incompletely answered.

This sense of incompletion becomes still more apparent in the second novel. Here I am heavily indebted to Callahan and Bradley's years of work in presenting Three Days Before the Shooting... out of the "mess" (Callahan and De Santis 605) of notes, typescripts, and computer files Ellison left behind. To convey a sense of the work's state, it might be enough to say that after her husband's death Fanny Ellison wanted simply to know: "Beginning, middle, and end. Does it have a beginning, middle, and end?" Callahan himself described what there was as "this huge, sprawling, somewhat incoherent, unfinished saga of multiple narratives" (Callahan and De Santis 605-606). It is striking simply to consider how much manuscript Ellison had amassed in the early 80s. And he nearly doubled this output on the computer to which he switched around the same time (Bradley 22). Beyond the 19 inches of manuscript that Ellison measured in March of 1982 for the New York Times's Herbert Mitgang (Rampersad 532), "he saved more than 3,000 pages in 469 files on eighty-three disks using three computers" (Bradley 22). As much as we might value the possibilities inherent in the fact that Ellison never finished making a novel of his second work, Callahan and Bradley's work

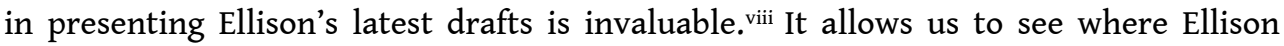
created strong narrative strands, as well as what he was still thinking through.

By the time he appeared in the typescripts of the second novel, Rinehart had become Bliss and Sunraider. One of Ellison's composition notebooks, dubbed the "Opus II" notebook after its inscribed subject line, and which represents a period of some creative overlap with Invisible Man (Bradley 121), ${ }^{\text {ix }}$ enables us to see where Ellison was still holding on, if with varied spellings, to Rinehart's name in notes for the second novel. But although the name will appear in the Opus II notebook and, much later, in the name and content of a computer file as late as the mid 1980s, neither of these will show up in the unfinished novel's narrative proper (138-139). Instead, Rine returned as Sunraider the adult and Bliss the child or, as Ellison sometimes refers to him in notes, Bliss-Sunraider. Unlike Rinehart in Invisible Man, Bliss-Sunraider has a pivotal and present role in much of the unfinished novel. Born of violent circumstances, Bliss is the light-skinned child of a white woman and an unknown father, raised by the black jazzman/preacher Alonzo Hickman and his church community as a symbol of hope for the future. The hefty symbolic weight given him as a child, and the role accompanying it in church performances-requiring him to remain for long periods in a specially built coffin, waiting and breathing through a tube so that he can rise up and make the congregation feel the resurrection-will sit well with neither the young Bliss nor the adult Sunraider: "Back to that? No!" (Ellison, Three Days 330).

We encounter Bliss after he has already become Adam Sunraider, and only in Sunraider's and Hickman's remembrances. By this point, Sunraider is a senator passing culturally and perhaps racially ${ }^{\mathrm{x}}$ for white, infamous for his inflammatory anti-black rhetoric; he has also left behind him his own light-skinned child, Severen, now grown up and dealing with an equally involved racial and painful background: because of Bliss-Sunraider's treatment and abandonment of her, Severen's mother commits suicide after giving birth to him. When Hickman learns that Severen aims to revenge himself upon his father by assassinating Senator Sunraider, he and his church group take off for the nation's capital to warn him, but are not permitted to see the Senator in 
time. The body of the novel, at least as it stood until the 1980s, is largely comprised of Hickman and Bliss-Sunraider's time in the hospital, as the Senator lies presumably dying from gunshot wounds. Together, they reminisce: remembering in silent asides and recollecting variations on the past. Up to a point, Sunraider is half of the unfinished second novel's voice.

As Ellison worked on computer drafts from 1982 to late December of 1993 (Callahan and Bradley, Three Days 485), he began to back away from Bliss-Sunraider. These files shift the emphasis to Hickman, as well as to a new cast of characters who recall and even exceed the picaresque, episodic quality of figures like Invisible Man's Peter Wheatstraw or Jim Trueblood. In the computer drafts made after the most solidly composed sections known as Book I and II, ${ }^{\text {xi }}$ Sunraider is missing except as an occasional point of discussion and a causal agent: his impending assassination serves to set Hickman on his journey. He does not appear in the narrative; he is, as Bradley has noted, reduced to "a plot device" (126). Whereas Hickman's arrival in Washington, D.C. to warn the Senator was originally written as a brief seven-page Prologue, it becomes in the computer files "more than three hundred pages unified by Hickman's governing consciousness" (Callahan and Bradley, Three Days 491). The long exchange in Book II, with Hickman at the Senator's hospital bedside, disappears: "Instead, the computer sequence places Hickman and his roving consciousness in the foreground." The substitution has met with mixed reviews. The Hickman sections in the computer drafts, as Three Days' editors note, often read more like Ellison essays than material for a novel (493). And why Bliss-Sunraider ceded his place in the narrative proper remains unclear.

If with a character like Rinehart and the kind of presence he maintains across Ellison's oeuvre there is the risk that contradictory yet plausible things can be said of him, trying to make consistent his chaotic presence poses problems. Ralph Ellison in Progress investigates Ellison's progress with the character and the character's namefrom "Rinehart" on one end to "Sunraider" on the other-thereby setting up Bradley's take on Ellison's eventual removal of Sunraider from the second work's main stage. Parsing Rineharts across texts and spellings delineates a timeline for the character and helps us understand its endpoint against this chronology. Yet although these distinctions avoid collapsing differences, the character also thereby loses its cumulative effect: dissected, it lies still. Attempting to answer the question of BlissSunraider's dismissal from the unfinished novel perversely makes less evident why Ellison might have been drawn to the character to begin with, and held onto him for something like half a century-and why, even as Sunraider's voice was written out, what remains of him still carries some dash.

The archival focus with which Bradley lays out the many Rineharts across Ellison's compositional history evidences the years he spent with Callahan examining Ellison's materials. Though the "Bliss" and "Sunraider" incarnations receive like treatment, Bradley spends the greatest time with the transmutations of the "Rinehart" name, and so for the moment we follow his focus here. Such a discussion, it should be said, requires a high degree of particularity in tracing differences that, while they might seem minute, are significant in interpreting a manuscript's development across time. As Bradley identifies the Rinehart manifestations, there are the "Rinehart" of Invisible Man; the "Rhinehart" of Ellison's Opus II composition notebook, whom Ellison had intended to be the protagonist of the second novel; and the "Rhineheart" of a later computer file. Bradley estimates the file to have been made in 1986 (138), its date 
suggesting that, at the time, Ellison would have been in the process of edging Sunraider out in favor of Hickman. On the broadest level in Ralph Ellison in Progress, the Rineharts exist on a spectrum between Invisible Man's Rinehart and the computer file's Rhineheart; Bliss and Sunraider follow Rhineheart in this progression. Serving as this trajectory's "middle ground" is the Rhinehart of the Opus II notebook (133). As the earliest manifestation, in this reading, Rinehart is the least burdened with the negative effects of identity evasion: "bitterness, self-hate, and shame" (136). Conversely, Rhineheart, and certainly Bliss, are "finally undone by them. This disparity is, perhaps, where Rinehart ends and Bliss begins."

Keeping this progression straight is made more difficult by a series of qualifications that are, or would need to be, made to the rules of spelling and corresponding qualities identified above. For example, although Ellison refers to the character as "Rhineheart" in the computer file addressed above, the identifying name that Bradley provides for the file is "Rhinehart" (138). And while Bradley says more than once that Ellison "spells the name throughout" the Opus II notebook as "Rhinehart" (125), I see a few "Rhinehearts" mixed up in the bunch. In a couple of places, Ellison's loopy cursive "e" appears before his rounded "a": for example, in the lines, "Rhineheart must function politically," "Rhineheart was never a babe," and most clearly, because not in cursive, in the note Ellison makes at the top of a page, spelling out Rine's full name: "Proteus Bliss Rhineheart" (Ellison, "Opus II"). Bradley is aware of the problem with holding Ellison to any of his spellings or ascribing them meaning. He writes in a note to his text, "Of course, one should not read too much into this, given that Ellison was a casual speller at best and wont to experiment with different spellings for many of his characters' names" (222, note 10). Ellison, for instance, often spelled "Rinehart" as "Rhineheart" and "Rhinehart" in the Invisible Man "notes and typescripts," and returned to the latter spelling in a 1958 essay (Bradley 130). xii Though Bradley separates out the different Rinehart spellings in part no doubt simply to address the character's change across time, by attaching different, self-consistent contents to each name, he nonetheless gives the spellings significance.

Moreover, clarifying one kind of nuance can cloud others. Since Ellison focuses on the character's lack of reliable substance when he wants at points to distance his affections from it, the consistency Bradley grants each of the Rine incarnations feels inconsistent with what we see in Ellison. One of Ellison's many undated notes for the second novel gives a fragment of Yeats's "Second Coming" (1919) as a gloss on the character: "Things fall apart; the centre cannot hold / Mere anarchy is loosed upon the world..."' (qtd. in Ellison, Juneteenth 358). In his strongest indictments of the character, Ellison sees its failure to embrace a stable center as one that will lead to social chaos: "anarchy is loosed upon the world." The earlier, Invisible Man Rinehart shares such a fault; he so lacks in essential content that the invisible man runs around wearing bits of his identifying markers, and these tokens sufficiently impart the role to him. Rind quickly conveys what heart there is. The internal consistency Bradley ascribes to each of the character aspects seems at odds with the fluid character that Ellison describes in the computer files: "A creation which turned out to be so swindle-prone, fluent, and shifty that absolutely no one could get him into focus" (Ellison, Three Days 699). One scarcely knows whether to use the masculine pronoun "he" when referring to the Rines, or whether the gender neutral, objectifying pronoun "it" is more appropriate, due to the character's decidedly amorphous tendencies. 
Ralph Ellison in Progress, however, proves able to get Ellison's creation strongly "into focus" in laying out, for example, the difference between the first novel's Rinehart and the intermediary Rhinehart: “Unlike Invisible Man's Rinehart, whose rootlessness is the form of his freedom, the Opus II Rhinehart is a victim of his own free will.... an individual particularly trapped by his racial indeterminacy, his protean ability to shift shades as well as shapes" (134). Invisible Man's Rinehart is partitioned off as the figure in whom rootlessness and freedom can go hand in hand, as if he were located before something like the biblical fall. Though we will soon resume following the trajectory Bradley lays out for the Rines, let us pause at this point where we might, in line with his reading, assume Ellison's take on the character to shift from Rinehart's form of free play to the more bound figure of the Opus II notebook Rhinehart. Rootlessness, at this point, would start to signify differently and less positively.

This recognition regarding rootlessness has some support in the Ellison canon. Indeed, a good part of Ellison's complex feelings toward the character might reasonably be said to revolve around this word "rootless" and the difficulty of synthesizing it with his strong investment in a stable national democracy and its citizenry. ${ }^{\text {iii }}$ But Bradley's attention to the (Rhine and Rine) characters' different relationships to rootlessness and indeterminacy is also notable because, as he offers it here in connection to the characters' names and compositional locations, the theory of an essential break within Ellison's treatment of the character is not fully substantiated. The idea that Invisible Man's Rinehart is free, while the Opus II notebook's Rhinehart is "trapped," not only seems questionable but also oversimplifies both ends of the spectrum it devises, collapsing tensions that Ellison left unresolved.

Seductive though it may be since he is a charismatic force in Invisible Man, such a ready equation of rootlessness and freedom in connection to Rinehart costs him some of his considerable interest. The invisible man makes a similar estimation of Rinehart as freedom impersonated, stating with certainty in the Epilogue that what he doesn't want is "the freedom of a Rinehart" (Ellison, Invisible Man 575). If "the freedom of a Rinehart" were as simple as it sounds, though, it would be harder to understand why Ellison found himself returning to Rine post Invisible Man, why the character held his attention for a more involved role in the second novel; instead, he came back to the character as if to see of just what this freedom consisted. It seems possible, in other words, that the freedom both Bradley and the invisible man interpret Rinehart as having, "the freedom of a Rinehart," is questionably simplistic $c^{\text {xiv }}$-the misreading of a narrator who sees it only from the outside and as hearsay. When the invisible man exclaims over Rinehart's previously unimaginable abilities, "His world was possibility and he knew it.... A vast seething, hot world of fluidity, and Rine the rascal was at home. Perhaps only Rine the rascal was at home in it" (498), this very "at home" suggests a complication to the fantasied rootlessness-as-freedom. Despite the challenge of performing a textual analysis of Rine's non-presence in the novel, we can draw some conclusions.

Whereas the invisible man is a visitor in this "seething, hot world," the idea that it is Rinehart's home place has significant implications, for as guests in other people's homes we often find their lives a nice and relatively unencumbered change of pace. The ramifications of the invisible man's twice-repeated recognition ("at home") might be extrapolated as follows. "Rine the rascal" is not free to leave this "world of fluidity" in the same way the invisible man is when he no longer needs a place to stay. Rinehart 
identifies with and is shaped by such a world; he is of it, and it has qualities that, as a guest not at home in such a world, the invisible man cannot imagine and is just as likely to misinterpret. Indeed, we know this world is Rinehart's because the invisible man can leave it and have no more to do with it...and Rinehart won't show up at his coal cellar, where we find our narrator in the Prologue and Epilogue. Even a chameleon like Rinehart is changeable in relationship to circumstance. Just as Hickman will later describe Sunraider as an addict in his running and shifting ("sapped by his running, drained and twitching like a coke fiend from all the twisting and turning that brought him here" (Ellison, Three Days 413)), Sunraider's fluidic nature actually a habit he cannot kick, and even with the Julius Franklin memories of his extended context edited out of Invisible Man, Rinehart is a creature of his world.

As quotation from Ellison reinforces this point, its language echoing Samuel Beckett's unappetizing take on habit: "Habit is the ballast that chains the dog to his vomit" (Beckett 8). In an undated note on the second work that strongly connects it to Invisible Man, Ellison writes: "Bliss Proteus Rhinehart returned to his part very much as a man to his mother or a dog to his vomit, and that's no lie" (qtd. in Ellison, Three Days 976). Rhinehart's role in the second work is a repeat performance, and Ellison's phrasing gives a specific quality to this return. In coming back to play his part, the master of chaos (Invisible Man 576) is in fact habit's creature or, more colloquially, its dog. Where Bradley argues that Rinehart's "rootlessness is the form of his freedom," I would submit instead that his rootlessness determines him in ways Bliss-Sunraider will strongly echo. "Rhinehart" may be the dog in this quotation, but he merely reprises a role "Rinehart" had already played well.

On a last note to my attempt to unsettle Bradley's demarcation of the Rines, here is a playful line from Ellison's Opus II notebook pertaining to Rhinehart: "(Rhinehart as Kilroy)." Actually, the "a" in "as" appears dotted, making it hard to tell whether the note reads "(Rhinehart as Kilroy)" or "(Rhinehart is Kilroy)." It is also possible that the dot is a period for the line above. Such uncertainty is fitting, given the rascally Kilroy Ellison likely means in this parenthetical thought. Readers might be familiar with the image if not the name of the WWII-era line-drawn figure: a dot-eyed man with his rounded nose and fingers peering over a wall or fence. Kilroy appeared etched, doodled, and graffitied in innumerable places; but although he gained historical solidity when he was engraved on the WWII Memorial in Washington, D.C., his source remains uncertain. Like Ellison writes in relation to Rhinehart-"When seized, he w[ill] assume different shapes" ("Opus II") ${ }^{\mathrm{xv}}$-Kilroy is impishly hard to pin down. Bradley's Opus II Rhinehart, the victim of his freedom, trapped by his indeterminacy, is hard to reconcile with Ellison's playful allusion to the cheeky, street-art Kilroy.

Rine is a "shifty" (Ellison, Three Days 699, qtd. above) character across Ellison's work, and pinning down this character seems to have the effect of making its creator less shifty as well. Such a result anticipates moments when Ellison himself yields to sterner moralism. In his essay "Society, Morality and the Novel" (1957), Ellison lists the major crises of the early $20^{\text {th }}$ century (among which he oddly includes the mutability of class lines), and then asks urgently, "How, in a word, can we affirm that which is stable in human life, beyond and despite all processes of social change?" (Collected 723-24). Ellison has his moments of protective conservatism; after all, here he almost sanctifies "stability" by attaching it to "human life." And, as I have said, he can be particularly insistent when it comes to the state of the nation and the promise of its democratic 
principle (á la Invisible Man's Epilogue). These moments potentially make agonistic his relationship to his protean creature, even if they never extinguish the aura of play the character continues to convey within the unfinished novel. Sunraider may become, as Ellison writes him, a race-baiting terror of an American senator, but Senator Sunraider has more than style: he is often written with style and half a grin. Effectively stabilizing Ellison by diagramming the character thus seems unfortunate, because it removes the very artful mystery where Ellison has overtly left it ("Kilroy") and preemptively gives in to Ellison's more stolid tendencies where the author has not done so himself, tipping the balance, as it were, in the kind of Ellison we get.

Putting Rinehart on the opposite end of the spectrum from Bliss-Sunraider proves impracticable, or at the very least undesirable, in the way it affects our sense of both characters, not to mention their author's greater subtlety. Though I do not support Steve Pinkerton's collapse of Sunraider and Rinehart in "Ralph Ellison's Righteous Riffs" (2011) as being alike "warnings" of the ills of improvisation (199), too polarizing a treatment of them has its own problems. Rinehart is not quite the freewheeler the invisible man supposes him to be when taking a trip in his look-alike glasses and hat, nor is he so separable, as we have seen in Invisible Man's earlier drafts, from the more earthbound concerns of racial passing and reactionism Bliss-Sunraider will embody in Three Days. And Bliss-Sunraider, in the opposite direction, exceeds merely enacting the trajectory and tragic cost of self-evasion, the drab role in which Bradley casts him and to which we will return: "The dichotomy embodied in Bliss/ Sunraider is Ellison's evocation of that process of acceptance and rejection" (139). The cost of laying out the boundaries between the Rineharts and Bliss and Sunraider, so as to explain Ellison's movement from one to the next, is that the ensemble, Rinehart \& co., thereby gets cheated of much of its appeal.

Even farthest chronologically from the Invisible Man Rinehart, Senator Sunraider -whom one fictional journalist describes as possessing "a mysterious charm, a charisma" (Ellison, Three Days 24)-is an extraordinary character whose greater and graver narrative development and historical anchoring does not cost him as much of Rinehart's enchantment as one might think. He need not even be present in a scene to leave his mark within the narrative's tone, giving it a strange levity. Take, for example, the following telephone exchange in Book I between journalists after the Senator's shooting. In this passage, McIntyre is the white, liberal journalist for whom Ellison wrote a uniquely first-person perspective:

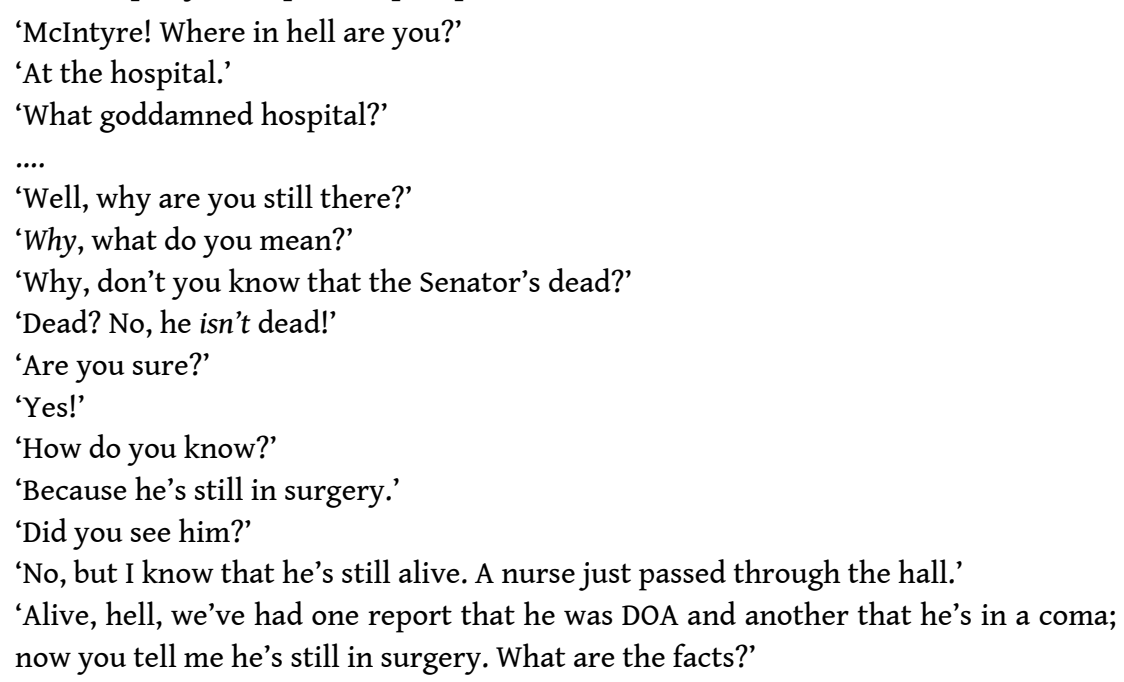


'I don't know yet. He might be in a coma, but they're still trying to save him. That's the latest word around here.'

'It had better be, McIntyre. And you stay there and get the latest facts. You stay there, you hear?'

'I'm sticking here,' I said. I hurried back upstairs with a growing sense of alarm. Suppose the Senator was dead? (Three Days 68; original italics)

McIntyre and the other journalist's exchange about so serious a situation, in combination with McIntyre's uncertainty ("Suppose the Senator was dead?") amid the certainty of his answers ("No, he isn't dead!"), creates an undercurrent of macabre merriment. The extended passage's point is not really to demonstrate journalistic miscommunication or the hush-hush atmosphere of a hospital dealing with a major governmental figure. Rather, it emphasizes and is inspired by the quality of Sunraider himself, which makes it hard to "get the... facts" because, to quote the "veteran "whitefolks-watche[r]"' (538), Millsap, who observes the slippery figure before he becomes a senator, "even under the most rigorous scrutiny, the rascal's image simply kept fading in and out of focus and reforming and realigning itself into so many ungraspable and shifting shapes that even the most knowledgeable and sociological of observers were utterly confused!" (699). xvi

Where Ralph Ellison in Progress sees "bitterness, self-hate, and shame" as finally undoing Bliss (136), and by extension determining Sunraider, who Bliss becomes, such a synopsis leaves as its remainder the delight of the above passages: "so many ungraspable and shifting shapes that even the most knowledgeable and sociological of observers were utterly confused!" Ellison was never, in any of his essays or interviews, a fan of the sociologists ${ }^{\text {xvii }}$; their confusion is his pleasure here, as is their baffling subject. Though Bradley will grant Ellison's "high regard" for Rinehart, and also "his acknowledgement of Bliss's ingenuity" (135-36), the sharply inflected fun running through both quotations ${ }^{\text {xiii }}$ is nowhere accounted for. Adding to the dark humor of the journalists' exchange is the line that ends Book I with ellipses nearly 200 pages later: "But at least the Senator was still alive..." (Ellison, Three Days 230).

Ellison gives Sunraider a biographical depth that Invisible Man denies Rinehart. But to extrapolate that he was also willing to remove the mystique from the character contradicts the longevity of Ellison's appreciation for his creation, an appreciation that seems bound up in the character's opacity. After his church group has come to Washington, D.C. with him to warn the Senator, Hickman realizes near the end of a separately written section, "Bliss's Birth" (1965), that the man they have been tracking all these years and who became Senator Sunraider might not be, indeed might never have been, Bliss. Though Hickman dismisses the thought a moment later, it is worth including here because, written, it proves less fleeting for the reader: "maybe the real one, the true Bliss got lost and this is somebody else. Because during all that time we could never ask if he really were the true son even though we knew in our heart he ought to be. Maybe we've been following the wrong man all this time" (479). Present here is the kind of disruptive play Bradley ascribes to Invisible Man's Rinehart. Though conceivably Ellison writes the suspicion only to allow Hickman to back away from it seconds after ("Naw, Hickman, you're tired, this was Bliss. There's no doubt about that" (479)), the doubt remains. Not only is Bliss not a "true son" to Hickman in any of the conventional senses (biologically or, except as a very young child, emotionally and situationally), but Ellison also has Hickman raise a question mark above Sunraider's head. Such a mark at the very least has a grim sense of humor: we are, after all, reading 
a long book largely about the trauma of Bliss's transformation into Sunraider. And at the most, it threatens to undermine our surety about who this Sunraider character might be, including his relevance to the main plot.

If swe relinquish a teleological approach to this set of figures, we can register more richly how oppositions remain fluid in Ellison. Simultaneous caprice and consequentiality, for instance, define a 1956 Ellison note sketching Bliss: “Blisses' [sic] purpose (immediate) is to get money to carry him further west. Secondarily and psychologically, it is to manipulate possibility and identities of the townspeople and to take revenge upon his own life. And to play!" (qtd. in Ellison, Three Days 975). Ellison opens the note with a diagnostic and humorless tone, but the phrase that finishes the quoted section yields to another sensibility, separating it from the first sentences both thematically and formally: "And to play!" The short, three-word phrase's enthusiasm and vigor, and its exuberant, impulsive punctuation belie the preceding, lengthier, more analytic character profile of Bliss. Though one could argue that Sunraider and Bliss are polar opposites (Bradley 139), the notes of play with which Ellison treats both characters complicate this reading. Hickman may have given Bliss an identity as a child that he eventually rejects; but in Ellison's note speaking of the character's spirit of selfrevenge, he still goes by "Bliss": the name for acceptance in Bradley's equation.

Clearly separating out Rinehart from Rhinehart and Bliss from Sunraider allows Ralph Ellison in Progress to offer a relatively succinct take on why first Rine and then Rhine get removed from the unfinished novel (their names never making it into the typescripts), and then Bliss and Sunraider fall out of its narrative foreground. Briefly, Rinehart and company's increasing marginalization is the result of Ellison's progressively giving them too much significance. As we have seen, the Opus II "Rhinehart" is weighed down in ways that remove him from the rootless freedom of Invisible Man's "Rinehart." And the computer file "Rhineheart" bears an even heavier load. Yet these more laden incarnations will still be lighter than Bliss and Sunraider as they get written in the unfinished novel; the Rinehart name and its variations disappear, finally, because of Ellison's increasing emphasis upon the "dichotomy embodied in Bliss/Sunraider" (139). The "two extremes" of Bliss and Sunraider edge out the earlier, "intermediary" identity, the very concreteness of their positions making so fluid a figure impossible.

Bliss and Sunraider follow a similar trajectory. Likewise burdened, they ultimately drop out of the text: "It may finally be that Bliss is too freighted with myth and symbolism; perhaps he stood for so much that Ellison could no longer endow him with life" (Bradley 127). Sunraider too gets "symbolic rhetoric" dumped upon him; "one also senses a tone of fatigue, a ponderousness that weighs down the fiction." As if so hung with meaning that they cannot remain within the unfinished novel, but having edged the Rines out in the process, they drop heavily out of the edits and narrative versions of the mid 1980s. What remains, unsurprisingly, after all this removal of dead weight is Rinehart's "spirit. An agent of transformation, Bliss Proteus Rinehart is a metaphor for the second novel as a whole, a way of explaining how Ellison could write for forty years without finishing his novel" (127). Rinehart's place becomes that of spiritus rector of the unfinished work, Rinehart's never-ending quality of flux its own.

Yet as I have tried to show, this argument relies on distinctions that when pressed become less certain. ${ }^{x i x}$ Bradley's reading is conceivably attractive in maintaining Rine as uncontainable by a position, but Bliss and Sunraider are not 
themselves placeholders, mere emblems of identity's acceptance and rejection, any more than Rinehart can be mobilized as their opposite in freedom. What I find more troubling about Bradley's own progress, however, beyond its segmentation of a character not so readily divisible, is its resulting conclusion. The play-within-structure Bradley attributes to Invisible Man's Rinehart seems to become relegated to the beyond of the unfinished work, blamed or commended for its role in Ellison's 40-year drafting process but not, finally, occupying the draft itself.

Perhaps no one who has both read Invisible Man and followed the extraordinary years comprising the second novel's drafting and incompletion can help but be pleased at the fitting metaphor aligning Rinehart's "Protean cast" with the second novel (Bradley 126). But where Ralph Ellison in Progress seems to want to move the spirit of play outside the second novel as the ethos of the latter's incompletion, we have already seen hints of the degree to which real-world weight and forms of play are mutually implicated in Ellison, so that so-called "ponderousness" never truly edges out play. Addressing the degree to which Ellison was both seduced and worried by his trickster's playful abilities (particularly when those abilities take the wily figure to the Senate floor, as in the case of Sunraider) would require a separate study. Yet it is nonetheless possible to suggest that the very kind of play and playacting that Bradley identifies and largely isolates in Rinehart, the trickster "know-how" (Ellison, Collected 110) so interesting to Ellison, ${ }^{\mathrm{xx}}$ is complicated rather than edged out by being given more developed historical resonances in the unfinished novel, as if the author were challenging his own affinities by placing them in the context of something else he held dear: American democracy in action. If anything, I would suggest that the commingling of these qualities, of play and seriousness, determines the fascination the character's shaping and reshaping held for Ellison as he continued work on the second novel. Going more firmly hand in hand than progress-oriented reading allows, transformative play and what I have called real-world weight continue to test each other across the Ellison oeuvre. Sectioning off "slides" of the character's formation disallows some of the complications that Ellison kept more alive, and which seemed to occupy his thought and challenge his allegiances for no small part of his career.

That Ellison never created a definitive draft of his second novel makes not only challenging but also conceivably unwise a final reading of the decisions he made there, even in his last reworked manuscripts and files. From all evidence, though, it does seem possible to surmise that Ellison found in the character he held onto for close to 50 years a locus to experiment with a set of conceptual tensions and inheritances that greatly intrigued and troubled him, located as they were in the place where power meets pleasure, and law its disorder. (Readers interested in learning more about Ellison's long-term attraction and resistance to the character will find rich material in, among other places, the Library of Congress collection of Ellison's papers, his essays over the years, and the draft documents that have been carefully collated for Three Days.) ${ }^{x \times i}$ It would stand to reason, then, that at varying points over the course of decades, these tensions were worked out differently in Ellison's thinking, and conceivably within the same text. If "Rinehart," "Rhinehart," or "Rhineheart" (or "Bliss" and "Sunraider") name anything at all, it may well be precisely this tracery of thought through Ellison. In some ways, then, trying to establish just why Sunraider becomes, like Rinehart, a figure relegated to the wings of his novel misses the point. Indeed, the second novel proliferates the passages of such lines of thought, via figures like Sunraider's son, Severen, whom Ellison will describe in notes as "the joker, the wild card. The 
unexpected emotional agent of chaos" (qtd. in Ellison, Three Days 974), and Love New: a man of slave origins, raised among Native Americans. A sly shifter and loquacious talker, he knows how to take advantage of his mixed up makeup, when to be one thing and when to be another (811); he is, as he says, "outside the enclosure" (816). xxii

Though Sunraider is the unfinished novel's most prominent instantiation of Ellison's mode of signifying upon the "American virtuoso of identity" (Collected 110), he is hardly the only one. He is, it seems fair to say, nothing more and nothing less than a possibility for the author who created him. Ellison appreciators, among whom Adam Bradley is clearly to be counted, will not be strangers to the challenge Ellison poses to our usually well intentioned attempts to categorize him. Similarly, I have no wish to make Ellison (or Rinehart!) a catchall for infinitely various positions, whether political or aesthetic. But it is the case that Ellison's complex intermixture of at times strongly conservative thought ${ }^{\mathrm{xxiii}}$ with revolutionary foresight and bravery ${ }^{\mathrm{xxiv}}$ makes him, in a game-changing way, both compelling and formidable as a subject of analysis. Readings oriented toward finding in Ellison a clear progression, even a negative one, come up against what in Ellison makes such a telos-oriented reading too limited and limiting.

As:Timothy Parrish argues in setting up his recent work, Ralph Ellison and the Genius of America (2012), both of Ellison's biographers fall into this trap. In 2002, Lawrence Jackson established Ellison's arrival at the point of writing Invisible Man as almost inevitable. This is also where Jackson's story of Ellison concludes, as if “Ellison's creative life and political commitment ended in 1953 when he won the National Book Award" for his first novel (Parrish 4). And in 2007, Arnold Rampersad told a story of decline following Invisible Man's publication, giving the sense, to quote Parrish again, of "a perpetual falling-away from that triumph" (5). Ellison's astounding collection of essays, which often leads me to think of him as an essayist first and a novelist second, and the frequent brilliance contained in his later manuscripts, however much they never became a cohesive, published second novel, argue the insufficiency of these kinds of readings.

Paprish's book sometimes seeks so much to correct unappreciative readings of Ellison that it too comes to inhabit this mode. Rather than approaching biography through literary history, Parrish inverts the model in addressing the second novel's incompletion. Ralph Ellison and the Genius of America virtually canonizes Ellison as a martyr ${ }^{\mathrm{xxv}}$ who put civic responsibility ahead of publishing. ${ }^{\mathrm{xxvi}}$ Writing the novel, writing another novel, was a "relatively small matter" (38) for the author when set against political obligations-a questionable interpretation of an author who professed writing his primary concern, xxvii but one that does important work for Parrish's narrative in setting Ellison up “as an American visionary” (41). More literarily-informed, Bradley's analysis provides groundbreaking work on Rinehart's literary history within the Ellison canon, paying admirable, painstaking attention to available materials, but it remains the case that Ellison's mode of living in thought does not necessarily reward an approach invested in the kinds of linearity dictated by the framework of progress.

Asswe come to his archive and experience the sometimes dubious freedom of making something of what he left unfinished, of the masses of material awaiting further study, Ellison will undoubtedly continue to surprise us with the rigorously dimensional and mobile quality of his thought. Letting him will be our task. 


\section{BIBLIOGRAPHY}

Beavers, Herman. "Documenting Turbulence: The Dialectics of Chaos in Invisible Man." Ralph Ellison and the Raft of Hope: A Political Companion to Invisible Man. Ed. Lucas E. Morel. Lexington: The UP of Kentucky, 2004. 193-217. Print.

Beckett, Samuel. Proust. New York: Grove Press, 1957. Print.

Bell, Kevin. "The Embrace of Entropy: Ralph Ellison and the Freedom Principle of Jazz Invisible." boundary 230.2 (Summer 2003): 21-45. Print.

Bradley, Adam. Ralph Ellison in Progress: From Invisible Man to Three Days Before the Shooting.... New Haven: Yale UP, 2010. Print.

Callahan, John F., ed. Juneteenth: A Novel. By Ralph Ellison. New York: Vintage International, 1999. Print.

Callahan, John F. and Adam Bradley, eds. Three Days Before the Shooting.... By Ralph Ellison. New York: The Modern Library, 2010. Print.

Callahan, John F. and Christopher C. De Santis. "'Some cord of kinship stronger and deeper than blood': An Interview with John F. Callahan, Editor of Ralph Ellison's Juneteenth.” African American Review 34.4 (Winter 2000): 601-620. Print.

Ellison, Ralph. The Collected Essays of Ralph Ellison. Ed. John F. Callahan. New York: The Modern Library, 1995. Print.

---. Conversations with Ralph Ellison. Ed. Maryemma Graham and Amritjit Singh. Jackson: UP of Mississippi, 1995. Print.

---. Invisible Man. New York: Vintage International, 1995. Print.

---. Juneteenth: A Novel. Ed. John F. Callahan. New York: Vintage International, 1999. Print.

---. “Opus II” composition notebook. Hickman Notes and Notebooks. Ralph Ellison Archive. Library of Congress. Container 141: Folder 6. Print.

---. Three Days Before the Shooting.... Ed. John F. Callahan and Adam Bradley. New York: The Modern Library, 2010. Print.

Foley, Barbara. Wrestling with the Left: The Making of Ralph Ellison's Invisible Man. Durham: Duke UP, 2010. Print.

Heise, Thomas. Urban Underworlds: A Geography of Twentieth-Century American Literature and Culture. New Brunswick: Rutgers UP, 2011. Print.

Jackson, Lawrence. Ralph Ellison: Emergence of Genius. New York: John Wiley \& Sons, 2002. Print.

Morel, Lucas E., ed. Ralph Ellison and the Raft of Hope: A Political Companion to Invisible Man. Lexington: The UP of Kentucky, 2004. Print.

Neal, Larry. “Ellison's Zoot Suit.” Ralph Ellison's Invisible Man: A Casebook. Ed. John F. Callahan. Oxford: Oxford UP, 2004. 81-108. Print.

Parrish, Timothy. Ralph Ellison and the Genius of America. Amherst: U of Massachusetts P, 2012. Print.

Pinkerton, Steve. "Ralph Ellison's Righteous Riffs: Jazz, Democracy, and the Sacred." African American Review 44.1-2 (Spring/Summer 2011): 185-206. Print. 
Porter, Horace A. Jazz Country: Ralph Ellison in America. Iowa City: U Iowa P, 2001. Print.

Posnock, Ross, ed. The Cambridge Companion to Ralph Ellison. Cambridge: Cambridge UP, 2005. Print.

Radford, Andrew. "Ralph Ellison and Improvised History." Midwest Quarterly 52.2 (Jan. 2011):

113-130. Print.

Rampersad, Arnold. Ralph Ellison: A Biography. New York: Alfred A. Knopf, 2007. Print.

Rice, H. William. Ralph Ellison and the Politics of the Novel. Lanham: Lexington Books, 2003. Print.

Yaffe, David. Fascinating Rhythm: Reading Jazz in American Writing. Princeton: Princeton UP, 2006. Print.

\section{NOTES}

i. A phrase borrowed no doubt from Ellison's hopeful and humorous statement prefacing the selection he published in Quarterly Review of Literature in 1969: "This excerpt from a novel-in-progress (very long in progress) is set in a hospital room..." (qtd. in Three Days 1065). The phrase used by Ellison, who kept hoping to produce his long-awaited novel, becomes argumentative when it titles Bradley's critical work on the author.

ii. And Bradley writes, Rinehart is "a character so charismatic that even his shadowed presence threatens to envelop Invisible Man as the novel nears its conclusion" (148).

iii. Rinehart seems to attract readings ranging the gamut from laudatory to condemnatory. See Heise 154, Radford 129, and Pinkerton 199 for the latter sensibility. Fans include Bell, who extols Rinehart as an "apotheosis of the nonidentitarian" (31), and Beavers, who celebrates Rinehart as a "figure... purely of the moment" (198).

iv. Credit goes to Bradley who in his 2010 work goes to some pains to establish the strong lineage joining Invisible Man's Rinehart to the unfinished novel's Bliss and Sunraider. See Bradley 121-39. Foley, who has spent a deal of time with the Invisible Man manuscripts, also and more briefly makes the case for this connection. See Foley 306.

v. Although Rice does not seem overly impressed by either Ellison or his politics, the unfinished novel clearly intrigues him. Unfortunately, he gives in to some facile formulations in conveying his sense of the cause behind the novel's non-arrival. Rice aligns Ellison's "incomplete novel" with his "incomplete political gestures" (4), and the invisible man's final hibernation with the unfinished state in which Ellison left the second novel's characters (128). More recently, Pinkerton takes on this question in an extended note, p. 205, note 11, debating which of Ellison's characters might have caused the biggest hurdle to finishing the novel. And Parrish seems to make the question one of his guiding curiosities: see, e.g., 17, 38, 78, 80-81, 178, and 221.

vi. It is impossible to give here a full range of instances pertaining to such one-sided readings or their opposition, but what follows provides a sense. The call for nuance in reading Ellison has been issued off and on for the last decade or more, though it sometimes overlaps with the kind of one-sidedness it seeks to counter. As Porter points out, "Ellison's critics and detractors, as well as some of his supporters, rarely seem interested in sorting through the nuances of his thought" (6). Ralph Ellison and the Raft of Hope, ed. Morel, was written largely to inject nuance into political interpretations of Ellison; the collection of essays, however, predominantly champions Ellison's civic mindedness.

Neal (who, as he "confesses" in his newer piece, once wrote in his Afterword to Black Fire (1968) that Ellison was no longer pertinent to black youth of his day) opens his deservedly famous essay, "Ellison's Zoot Suit," with a request for subtlety: "He cannot be put in any one bag and conveniently dispensed with. Any attempt to do so merely leads to aesthetic and ideological 
oversimplifications" (81). The same aim is put forth by The Cambridge Companion to Ralph Ellison, as editor Posnock establishes it in asking for the "relaxing of defenses" (2) when it comes to reading Ellison. Such openness is needed when it comes to confronting "the various static images affixed to Ellison over the decades. Lambasted by the Black Arts movement of the 1960s as apolitical, canonized by white liberals and neoconservatives as an icon of blandly affirmative Emersonian individualism, Ellison has suffered both caricatures." In a different register, Yaffe upholds Ellison's divergent aesthetic tendencies by suggesting that he "was a transgressive novelist and traditionalist jazz critic." He was, i.e., by turns avant-garde and nostalgic, depending on the context (10).

Even Barbara Foley's rigidly Marxist critique seeks to inject nuance into understanding Ellison, so that the anti-Marxism of the published Invisible Man can be understood within the context of the author's (and his original drafts') earlier affinities to class arguments. Most recently, Parrish has written Ralph Ellison and the Genius of America in reaction to Rampersad's reductionism in his Ellison biography. As Parrish writes, "This vein of response continued through the 1960s and '70s as some readers questioned Ellison's authenticity as a 'black' intellectual, while others suggested that Ellison has failed of his promise because he did not publish a second novel. The dubious achievement of Rampersad's book was to combine these two strains into one" (ix). Parrish, conversely, describes Ellison's incredible political foresight (28), establishing him "among the most politically engaged authors in the literary canon" (12).

vii. See also Bradley 125.

viii. More, Callahan and Bradley provide in Three Days a selection of Ellison's notes on the novel (Callahan does the same in Juneteenth). These notes, housed in full at the Library of Congress, also prove valuable when it comes to interpreting Ellison's narrative intent and accessing his character considerations, which with Rinehart, as I have said, often continue to seem unsettled.

ix. For ease of use, in my citations I follow Bradley's designation of the notebook as the "Opus II" notebook. The notebook is currently held at the Library of Congress, though locating it can be difficult: it took the generous assistance of Patrick Kerwin in the library's Manuscript Division to track down the notebook. Where Bradley gives its location as box 152, folder 6 in the Library of Congress's holdings of the Ralph Ellison Archive (Bradley 221, note 1), my bibliographic citation locates the notebook where it has most recently been found: within the Hickman "notes and notebooks." At the time of this essay's drafting, it was located in container 141, folder 6.

x. See Ellison, Three Days 472. Hickman: “I still couldn't tell who your daddy was, or even if you have any of our blood in your veins...."

xi. The second largely became what Callahan published as Juneteenth and focuses heavily on Hickman and Bliss's relationship.

xii. See Ellison, "Change the Joke and Slip the Yoke," Collected 110. In this essay he also reveals, I believe for the first time in print, B. P. Rhinehart's full name: "(the P. is for 'Proteus,' the B. for 'Bliss')." Ellison seems to have known the full name sooner, although he was still playing with its ordering; he jotted "Proteus Bliss Rhineheart" in the Opus II notebook.

xiii. See, e.g., Ellison's 1957 essay, "Society, Morality and the Novel," in Collected 694-725.

xiv. Love New seems to anticipate this point in Ellison, Three Days 850 . He says to Severen, "you're free to come and go...you are free. But the real question is what is this freedom? What are its boundaries?"

xv. Here, at the top of a page in the Opus II notebook, Ellison is writing a note on the character's namesake, Proteus.

xvi. Hickman had asked Millsap to follow and observe Bliss after he ran away from home and the church community; although Millsap is thus describing Bliss in his pre-Sunraider days here, the quotation still very much applies to the rascal-become-Senator.

xvii. Such examples are numerous. See, e.g., Ellison, Conversations 197: "C: I know you have never had much faith in the sociologists' approach to Black problems. Are you still against them? E: Not 
all [Chuckles.]" See also Ellison's Introduction to Invisible Man xv: "Thus despite the bland assertions of sociologists...." And Ellison, Collected 726: "They only abstract it and reduce it to proportions which the sociologists can manage."

xviii. The first is from Ellison's earlier typescripts and the second from the computer files. Callahan and Bradley give the dates for Book I as lying somewhere between the mid-50s and, as it was last revised, the early 70s (Callahan and Bradley, Three Days 3). Millsap's letter, from what Callahan and Bradley call the "Hickman in Georgia \& Oklahoma" files, would likely date from the 80 s, and have been revised at least as late as 1988 (486).

xix. Where Bradley, for instance, sees the dividing break between Rhinehart and Rhineheart taking place in Ellison's 1980s computer file, in which Ellison notes Rhineheart's rejection of "'his human center" and locates that center "'in his cultural background as a Negro"' (qtd. in Bradley 139), I fail to see a substantial psychological, cultural, or historical weight thereby added that did not already exist when Ellison wrote about the Rhineh(e)art character in the Opus II notebook, some 30 years earlier: "The problem of color is there, as psychological self-rejection, as reason for questioning, as main source of his sense of rootlessness, He cannot accept his Negro identity except as something to exploit" ("Opus II").

xx. On Ellison and the trickster see, e.g., "The Little Man at Chehaw Station," Collected 496. On Ellison's beloved Louis Armstrong as trickster, see also "Change the Joke and Slip the Yoke," Collected 106.

xxi. Suggested primary source reading includes "Working Notes for Invisible Man" (undated, post-1945) in Ellison, Collected 341-45; "Harlem Is Nowhere" (1948) in Collected 320-27; Invisible Man (1952); "The Art of Fiction: An Interview" (1954) in Ellison, Conversations 6-19; "Change the Joke and Slip the Yoke" (1958) in Collected 100-112; "The Little Man at Chehaw Station" (1977-78) in Collected 489-519; Juneteenth (1999); and Three Days Before the Shooting... (2010). On Ellison's investment in American democracy and, sometimes, in national stability, see, e.g., "Society, Morality and the Novel" (1957) in Collected 694-725 and "What America Would Be Like Without Blacks" (1970) in Collected 577-84.

xxii. That the characters are related patterns upon an interest becomes more apparent in the Opus II notebook, where Ellison plays with making "Love...Rhine's Daddy," or "(Rhinehart by blood...Negro, White, and Indian.)"; and Ellison seems in places undecided as to who will be the hero, Rhinehart (later Sunraider) or his son (Severen).

xxiii. Such conservatism can be found along both political and aesthetic lines. Regarding the former, e.g., Ellison's staunch support of President Johnson is well known, as is, more relevantly here and in connection to his long relationship with Johnson, Ellison's adamant refusal to criticize the Vietnam War. Regarding the latter category, e.g., Ellison's sometimes strangely emphatic aversion to bop is legendary-and potentially surprising given his frequently experimental style in his novelistic work.

xxiv. Parrish makes such foresight and bravery the constant chorus of his 2012 study, albeit with ample support.

xxv. See Parrish 215, e.g.: "In his case, the invisible author, who was also the invisible victim, was willing to be responsible for the fate of all Americans."

xxvi. See Parrish 38. Ellison might have wanted to publish another novel, but, building on Danielle Allen's work, Parrish suggests that Ellison did not because he knew "America needed the example of leaders and intellectuals ready to jettison the Jim Crow principles that had defined American citizenship, needed that example more than it needed the entertainment that novels provide."

xxvii. Ellison repeatedly emphasizes his primary role as writer. See, e.g., Ellison, Collected 211: "I wasn't, and am not, primarily concerned with injustice, but with art." See also, Ellison, Conversations 101: “'I am a novelist, not an activist...” These quotations date from 1955 and 1966, respectively. 


\section{ABSTRACTS}

Since Ralph Ellison's death, the draft materials of his second, unfinished novel have become available, in addition to his notes for Invisible Man (1952). This article encourages literary interpreters to exercise restraint in retroactively imposing narrative order and coherence upon the author's incomplete work and working materials. Taking as an example the character Rinehart, who appears in varying forms throughout Ellison's career, this article traces and interrogates the character's treatment in the work of exemplary Ellison critic Adam Bradley to demonstrate that the urge to create a linear interpretive model diminishes not just the character but also Ellison's considerable nuance. Focused character interpretation ultimately makes the larger case that coming to Ellison's archive, as well as his published works, requires flexibility adequate to the author's own mobile habits of thought and composition.

\section{INDEX}

Keywords: African-American literature, archive, interpretation, Invisible Man, Ralph Ellison, Rinehart, Three Days Before the Shooting...

\section{AUTHOR}

CHERYL ALISON

School of the Museum of Fine Arts, Boston 